Bangladesh J. Bot. 49(4): 1053-1062, 2020 (December)

\title{
EFFECTS OF A MARINE DIATOM SKELETONEMA COSTATUM EXTRACT ON LUMINESCENCE DISEASE CAUSING VIBRIO HARVEYI DURING PENAEUS MONODON LARVICULTURE
}

\author{
Krishnamoorthy Sivakumar ${ }^{1}$ ANd SUdalayandi KanNAPPaN* \\ Crustacean Culture Division, ICAR, Central Institute \\ of Brackishwater Aquaculture, 75 Santhome High Road, MRC Nagar, \\ Chennai - 600 028, Tamil Nadu, India
}

Keywords: Skeletonema costatum, Antagonism, Luminescence disease, Shrimp larviculture

\begin{abstract}
The crude extract of Skeletonema costatum obtained through cold extraction method was characterized for its phytochemicals, using FTIR and GC-MS. The antagonism of S. costatum extract was tested against Vibrio harveyi, its various virulence factors, and also tested against Vibrio harveyi during Penaeus monodon larviculture. S. costatum extract, controlled the growth of $V$. harveyi. The zones of inhibition were $12.6 \pm$ $0.2,6.6 \pm 0.1$ and $3.7 \pm 0.1 \mathrm{~mm}$ at 300,200 and $100 \mu \mathrm{g}$, respectively. The production of bio-luminescence was also reduced to 10.0, 11.0, 20.0, 25.0 CPS. The extract contained fatty acids such as 16-octadecanoic acid $(48.05 \%)$ and pentadecanoic acid $(18.94 \%)$ as evidenced by GC-MS. S. costatum extract revealed various compounds viz., alcohols, phenols, etc, which are responsible for controlling $V$. harveyi and virulence factors. During P. monodon larviculture, S. costatum extract at $200 \mu \mathrm{g} / \mathrm{ml}$ showed reduction $(\mathrm{p}<0.05)$ in the cumulative percentage of mortality caused by $V$. harveyi $(35.20 \pm 0.6 \%)$ as compared to control $(76.30 \pm$ $0.8 \%$ ). It can be concluded that $S$. costatum extract may be used to control disease-causing $V$. harveyi during shrimp larviculture.
\end{abstract}

\section{Introduction}

Worldwide demand for shrimps has remarkably improved and sea catches are deficient to meet out, consequently, shrimps are grown in an intensive way. Development of aquaculture has been distinctive in displaying the overpowering modifications in global fish/shrimp production for many years. The advancement in aquaculture resulted in the emergence of growing unknown diseases (Tandel et al. 2017). Opposing influences of aquatic diseases on the production of global aquaculture are distressing. Amongst disease-causing agents, Vibrio harveyi, a bio-luminescent bacterium has been found to cause $80-100 \%$ mortality among the postlarvae of shrimp hatcheries (Raissy et al. 2011). In order to govern shrimp's health various types of chemicals are used on a large scale. Controlling of bacterial diseases by preservatives during shrimp culture practices, may develop resistance among them. Therefore, alternate eco-friendly resources may be explored to control shrimp diseases. Seaweeds produce plentiful bioactive molecules which may be valuable as an antimicrobial agent against aquatic bacteria. The leaves extract of a mangrove plant, Rhizophora apiculata was evidenced to control Vibrio harveyi (Kannappan et al. 2018) during shrimp larviculture. The crude extract of the marine herb, Sesuvium portulacastrum and macro algae, Ulva spp. has been established to control V. harveyi (Dineshkumar et al. 2017a) and other bacteria during shrimp larviculture.

Skeletonema costatum, a marine diatom, inhabited near the shore waters of the sea, forms the feeding ground for crustacean larvae which has been designated to have many bio-active compounds (Prartono et al. 2013) and its antibacterial activity has been tested on fish and shellfish borne bacterial pathogens (Naviner et al. 1999). The crude extract of $S$. costatum was found to be inhibitory on V. anguillarum and other pathogens such as Klebsiella pneumonia and Salmonella

\footnotetext{
*Author for correspondence: <sudalikanna@gmail.com>. ${ }^{1}$ ICAR-Krishi Vigyan Kendra, Tamil Nadu
} Veterinary and Animal Sciences University, Kattupakkam-603 203, Tamil Nadu, India. 
typhi (Shanmugapriya and Ramanathan 2011). V. harveyi has been well-known as one of the disease-causing bacteria for various fish/shrimps as it produces virulence factors such as bioluminescence, proteases, phospholipases, lipases, siderophores, chitinases and haemolysins (SotoRodriguez et al. 2012).

Lipids and fatty acids from marine algae have been recognized to antagonize microbes by disruption of their cell membrane (Bergsson et al. 2011). Maintaining primary productivity in the fish/shrimp grow-out ponds through microalgae had shown the inhibitory effect against luminous $V$. harveyi (Tendencia et al. 2006). The present investigation was focussed on the antagonism of crude extract, $S$. costatum against growth and virulence of the luminescence disease-causing $V$. harveyi during shrimp larviculture. Characterization of various functional compounds from the extract by Fourier transform infrared spectroscopy (FTIR), Gas chromatography and mass spectroscopy (GC-MS) and then testing against luminescence disease causing $V$. harveyi during $P$. monodon larviculture was carried out.

\section{Materials and Methods}

Vibrio harveyi strains were isolated from the infected Penaeus monodon and then identified and confirmed by PCR (Maiti et al. 2009). The strains were stored in Luria-Bertani (LB) broth with sterile glycerol $(15 \% \mathrm{v} / \mathrm{v})$ and named them as $V$. harveyi 1 to $V$. harveyi 20 for further use. $V$. harveyi (MTCC 3438) was used as a reference strain.

Skeletonema costatum was collected from the Muttukadu lagoon, Chennai, India using $10 \mu \mathrm{m}$ plankton net and then observed under the microscope. The cells were observed as cylindrical with long tubular structure and then mass cultured in out-door FRP tanks (5000 litres) using Guillard's medium (F/2 medium, Guillard and Ryther 1962) with aeration at $28^{\circ} \mathrm{C}$. The cells were collected using a plankton net $(10 \mu \mathrm{m})$. The collected algae were shade dried, then stored at $4^{\circ} \mathrm{C}$, later used for extraction. One gram of dried $S$. costatum powder was mixed in $10 \mathrm{ml}$ of ethyl acetate and shaker incubated at $30^{\circ} \mathrm{C} @ 50 \mathrm{rpm} / 96 \mathrm{hrs}$ for extraction of compounds called as "Cold extraction method" (Das et al. 2005). Afterwards, the extracts were filtered by Whatman filter paper (No.1), rotary evaporated at $30^{\circ} \mathrm{C} / 3 \mathrm{hrs}$ and then stored in darkness at $4^{\circ} \mathrm{C}$. For antibacterial activity, the extract was liquefied with $5 \mathrm{mg} / \mathrm{ml}$ of 30\% (v/v) DMSO (Dimethyl sulfoxide) and tested against $V$. harveyi through Agar well diffusion assay (Chellaram et al. 2011). DMSO @200 $\mu \mathrm{lof} 30 \%$ $(\mathrm{v} / \mathrm{v})$ was used as control. MIC was evaluated against $V$. harveyi. S. costatum cells alone were evaluated against $V$. harveyi for antagonism (Yamasaki et al. 2011). Ten $\mu \mathrm{l}$ of $V$. harveyi (2.19 $\left.\times 10^{7} \mathrm{cfu} / \mathrm{ml}\right)$ and $100 \mathrm{ml}$ of $S$. costatum cells $\left(10^{5}\right.$ cells $/ \mathrm{ml}$ or $\left.0.151 \mathrm{OD}_{700}\right)$ was inoculated in $\mathrm{F} / 2$ medium and co-cultured for 5 days. For inhibition, $2 \mathrm{ml}$ of co-culture broth was analyzed for mean differences of $V$. harveyi counts between the control and treatments as observed in darkroom as well as determined using Vibrio harveyi Selective Agar (VHSA) medium. The mean differences of $S$. costatum counts were estimated by Sedgewick counting chamber. Agar overlay method (Chellaram et al. 2011) was used to study about antagonism of S.costatum cells against V. harveyi. Initially $S$. costatum was grown $\left(10^{5}\right.$ cells/ml or $\left.0.151 \mathrm{OD}_{700}\right)$ in $\mathrm{F} / 2$ medium, then centrifuged and spotted $(50 \mu \mathrm{l})$ on agar containing $\mathrm{F} 2$ medium and incubated for $96 \mathrm{hrs} / 28^{\circ} \mathrm{C}$. V. harveyi cells were grown $\left(2.19 \times 10^{7} \mathrm{cfu} / \mathrm{ml}\right)$ overnight in LB broth at $28^{\circ} \mathrm{C}$, and inoculated $(20 \mu \mathrm{l})$ into semi-solid LB agar medium and poured over the spotted $S$. costatum cells. After 24 hrs of incubation, the zone of inhibition around $S$. costatum indicated as an inhibition on $V$. harveyi.

Extract of $S$. costatum $(300 \mu \mathrm{g} / \mathrm{ml})$ was taken in $100 \mathrm{ml}$ of LB medium. V. harveyi cells (500 $\mu \mathrm{l}$ of $2.19 \times 10^{7} \mathrm{cfu} / \mathrm{ml}$ ) were inoculated and incubated at $28^{\circ} \mathrm{C} / 100 \mathrm{rpm} / 5$ days in a shaker incubator. The growth of $V$. harveyi with virulence factors such as luminescence, protease, crude bacteriocin, exopolysaccharide was measured by the spectrometer. The Phospholipase, 
proteolysis, lipolysis and thermonuclease were tested based on the hydrolysis of the medium in the plate assay. The activities were marked with qualitative parameters as weak, moderate, high and very high. Surface hydrophobicity was determined by salt aggregation test (SAT) as the lowest molarity of ammonium sulfate $(0.05-4.0 \mathrm{M})$ that caused visible agglutination by $V$. harveyi and Cell adhesion to hydrocarbons Test (BATH) (Soto-Rodriguez et al. 2012). For estimation of luminescence, the spent culture of $V$. harveyi was used and reading was observed in $10 \mathrm{sec}$ as light emission by Luminometer (Perkin Elmer) after shaking the plates and expressed as counts per second (i.e., photons per second). For determining various functional compounds, the shade dried extract was powdered and compounds were detected and recorded using BRUKER IFS 66 model FTIR spectrometer (D'Souza et al. 2008).

GC-MS analysis was performed (Elumalai and Sakthivel 2013) using JEOL system (Joel, GCMate II, Akishima, Tokyo, Japan) equipped with a mass selective detector with a capillary column $(30 \mathrm{~m} \times 0.25 \mathrm{~mm} \times 0.25 \mathrm{~mm})$ using helium at $1 \mathrm{ml} / \mathrm{min}$ as a carrier. Peaks identification from crude $S$. costatum extract was identified by comparison with retention times of standards. The mass spectra obtained were compared with those available in the installed NIST libraries.

PCR tested postlarvae (PL17) of P. monodon, procured from a private shrimp hatchery was acclimatized to saline water @20 PSU (Practical Salinity Unit) for 5 days $/ 28^{\circ} \mathrm{C}$. The challenge tests were carried out in 3 plastic tubs (50 litres), disinfected prior with $10 \mathrm{mg} / \mathrm{l}$ of $\mathrm{KMnO}_{4}$ $(\mathrm{w} / \mathrm{v}) / 10 \mathrm{~min}$ and filled with 20 litres of saline water (20 PSU). The control tub was inoculated with $V$. harveyi alone $\left(10 \mathrm{ml}\right.$ of $\left.1.80 \mathrm{OD}_{600}\right)$. The second tub was treatment, where PL was inoculated with $V$. harveyi. Then $200 \mu \mathrm{g}$ of $S$. costatum extract per $\mathrm{ml}(2 \mathrm{gm} / 10$ litre) of saline water. The third tub was a control where $S$. costatum extract was added $(200 \mu \mathrm{g} / \mathrm{ml})$ in saline water alone with PL and without $V$. harveyi (Kannappan et al. 2018). The PL feed $\left(\mathrm{CP}^{\mathrm{TM}}\right)$ was given twice/day @15\%. The experimental tubs were covered at the top to avoid contamination (Traifalgar et al. 2009). The mortality of PL was ascertained by counting the number of dead larvae. The total heterotrophic bacteria and $V$. harveyi counts were determined using a selective medium. All the experiments were executed in triplicate and expressed as means with SD. Data obtained were analyzed by ANOVA using SPSS software version 16.0. The significance level was kept at $\mathrm{p}<0.05$.

\section{Results and Discussion}

The biomass of $S$. costatum cell density showed $2.56 \pm 0.2 \mathrm{~g} / \mathrm{l}$ (WWB) and $0.216 \pm 0.01 \mathrm{~g} / \mathrm{l}$ in (DWB) in out-door culture. The extract of $S$. costatum showed a zone of inhibition of $12.9 \pm$ $0.2,6.6 \pm 0.1$ and $3.7 \pm 0.1 \mathrm{~mm}$ at 300,200 and $100 \mu \mathrm{g}$, respectively against $V$. harveyi (Table 1). In control, DMSO did not show any inhibition. This study revealed that $200 \mu \mathrm{g}$ of $S$. costatum extract was inhibitory to $V$. harveyi $(6.8 \pm 0.2 \mathrm{~mm})$ and the same concentration of the extract was found to inhibit the growth of $V$. harveyi during shrimp larviculture. When S. costatum cells (50 $\mu \mathrm{l})$ alone $\left(9.13 \times 10^{5}\right.$ cells $\left./ \mathrm{ml}\right)$ were spotted on an agar plate, $17.30 \pm 0.1 \mathrm{~mm}$ was observed as an inhibitory zone against the growth of V.harveyi. Marine microalgae such as Chlorella vulgaris, Spirulina platensis and Nannochloropsis bacillaris also showed antagonism against Vibrio sp. (Dineshkumar et al. 2017b).

During co-culture, $S$. costatum reduced the growth of $V$. harveyi from $2.32-0.47 \operatorname{logs}$ from 1 st to $5^{\text {th }}$ day whereas, in control, it varied from $3.38-3.11 \log$. The differences from 1 st day to 5 th day ranged from $1.06-2.64$ logs. During co-culture, $S$. costatum, varied from $8.32 \times 10^{5}$ to $9.13 \times 10^{5}$ cells $/ \mathrm{ml}$ from 1 st to 5 th days, but in control, S. costatum showed from $8.29 \times 10^{5}$ to $9.09 \times 10^{5}$ cells $/ \mathrm{ml}$. The difference among the cells was observed as $3.0 \times 10^{3}$ to $4.0 \times 10^{3} \mathrm{cells} / \mathrm{ml}$ from 1 st to 5 th day (Table 2). This study confirmed that $S$. costatum cells reduced the load of $V$. 
harveyi, 1.06 - $2.64 \log$ as compared to control $(3.38-3.11 \mathrm{log})$. Similarly, Tendencia et al. (2006) had reported inhibition on V. harveyi (3.0 logs) by co-culturing with Chlorella spp. While treating $V$. harveyi with $S$. costatum extract, the growth of $V$. harveyi reduced from 1st to 5 th day. The highest growth difference was observed on 3rd day $(0.375$ OD) and lowest on 1st day $(0.223)$ as compared to control. The maximum reduction on bacteriocin production was $0.231 \mathrm{OD}$ on 3rd day and minimum $(0.051 \mathrm{OD})$ was observed on 2 nd day (Table 3$)$. However, the reduction of crude extracellular protein released was noticed daily in all the treatments.

Table 1. Antagonism of $S$. costatum extract against $V$. harveyi through agar well diffusion assay.

\begin{tabular}{lcccc}
\hline \multirow{2}{*}{ Extract } & \multicolumn{4}{c}{ Zone of inhibition $(\mathrm{mm})$} \\
\cline { 2 - 5 } & $100 \mu \mathrm{g}$ & $200 \mu \mathrm{g}$ & $300 \mu \mathrm{g}$ & DMSO \\
\hline S. costatum & $3.7 \pm 0.1$ & $6.6 \pm 0.1$ & $12.9 \pm 0.2$ & $0.0 \pm 0.0$ \\
\hline
\end{tabular}

Table 2. Growth of $S$. costatum during co-culture with $V$. harveyi.

\begin{tabular}{lllllll}
\hline \multirow{2}{*}{ Tests } & \multicolumn{5}{c}{ Cell counts (cells/ml) } \\
\cline { 2 - 7 } & Inoculation day & Day 1 & Day 2 & Day 3 & Day 4 & Day 5 \\
\hline S. costatum (Control) & $8.12 \times 10^{5}$ & $8.29 \times 10^{5}$ & $8.52 \times 10^{5}$ & $8.75 \times 10^{5}$ & $8.89 \times 10^{5}$ & $9.09 \times 10^{5}$ \\
S. costatum and V. harveyi & $8.15 \times 10^{5}$ & $8.32 \times 10^{5}$ & $8.54 \times 10^{5}$ & $8.81 \times 10^{5}$ & $8.92 \times 10^{5}$ & $9.13 \times 10^{5}$ \\
Difference in cell counts & $-3 \times 10^{3}$ & $-3.0 \times 10^{3}$ & $-2.0 \times 10^{3}$ & $-6.0 \times 10^{3}$ & $-3.0 \times 10^{3}$ & $-4.0 \times 10^{3}$ \\
\hline
\end{tabular}

The production of luminescence by $V$. harveyi was reduced to 10.0, 11.0, 20.0, 25.0 CPS for 4 days, compared to control (39.6, 50.3, 59.3 and 63.6) (Fig. 1). The maximum reduction on luminescence was observed on 4th day (25 CPS) and minimum on day 1 (10.0 CPS). In treatments, a moderate level of reduction on phospholipase and proteolysis was noticed from 1st to 5 th day. However, moderate level of lipolysis and thermonuclease activities were observed on 1st to 3rd, 4th and 5th days as compared to control (very strong). In the SAT test, $V$. harveyi as a control revealed strong hydrophobic activity from 1 st to 5 th day whereas, in treatment $V$. harveyi showed moderate hydrophobic activity from 1 st to 5 th day.

Microalgae possess extracellular products that can influence the microbes and their surroundings (Natrah et al. 2014). Skeletonema marinoi and other diatoms are well-known to produce toxic polyunsaturated aldehydes (PUAs) in response to cell damage that can affect different organisms including bacteria (Taylor et al. 2009). V. harveyi was well-known to produce extracellular compounds that are deliberated as the essential virulence determinants of V.harveyi (Soto-Rodriguez et al. 2012). In microalgae, fatty acids get congregated in the lipids of cell membranes which will be released by host lipolytic enzymes during cellular disintegration. Further, fatty acids are active antimicrobial compounds and related protection may be afforded to microalgae under stressful conditions from pathogenic microbes (Rangaia et al. 2010). Here, exopolysaccharide and protease production by $V$. harveyi was slowly reduced due to the extract of $S$. costatum as compared to control. The differences of pathogenicity among $V$. harveyi isolates revealed that proteases, hemolysins, phospholipase and other exotoxins may exert substantial roles in the virulence of $V$. harveyi (Austin and Zhang 2006).

The FTIR spectrum of $S$. costatum had shown different functional groups such as alcohols, phenols, unsaturated esters, aldehydes and ketones, esters, ethers, alkenes, primary amines, nitro compounds, aromatics and carboxylic acids, etc. (Fig. 2). Similar values were reported for 
Chlorella vulgaris (Duygu et al. 2012). The absorption spectrum of FTIR analysis exhibited 5 important peaks like aldehyde $(\mathrm{C}=\mathrm{O})$, esters $(\mathrm{C}-\mathrm{O})$, methylene $\left(\mathrm{CH}_{2}\right)$, methyl $\left(\mathrm{CH}_{3}\right)$, and hydroxyl bond absorptions $(\mathrm{O}-\mathrm{H})$, which were also sturdy in lipid content for many microalgae species (Yin et al. 2011). Marine algae produce fatty acids like tetradecanoic acid, hexadecanoic acid, octadecanoic acid methyl esters etc. (Musharraf et al. 2012) that show bioactivity. In this study, the antagonism of $S$. costatum against $V$. harveyi may be due chemical constituents such as 16octadecanoic acid, methyl ester (48.05\%) followed by pentadecanoic acid, 13-methyl, methylester $(18.94 \%)$.

S. costatum extract against Luminescence of Vibrio harveyi

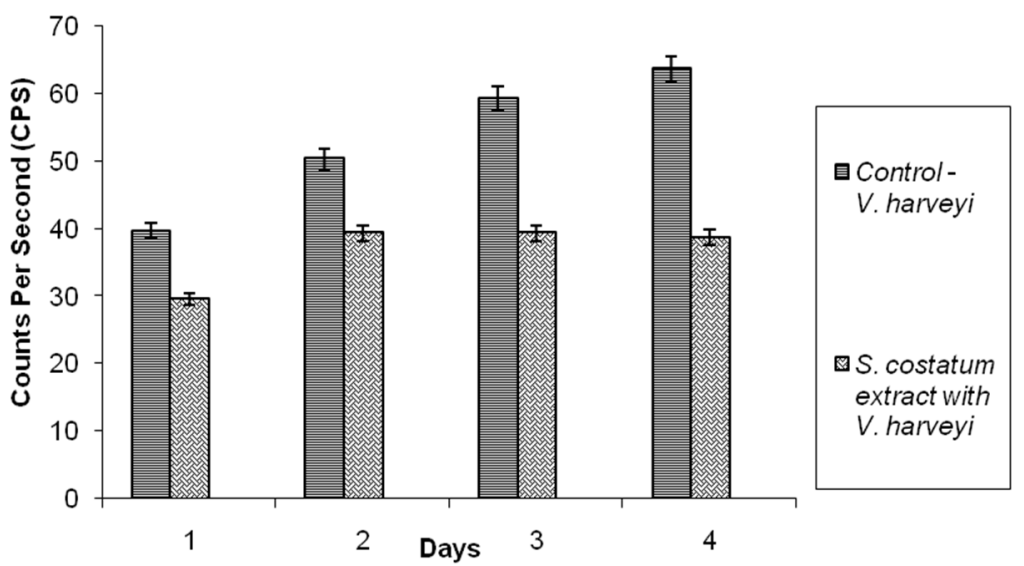

Fig. 1. Effects of $S$. costatum extract against luminescence produced by $V$. harveyi.

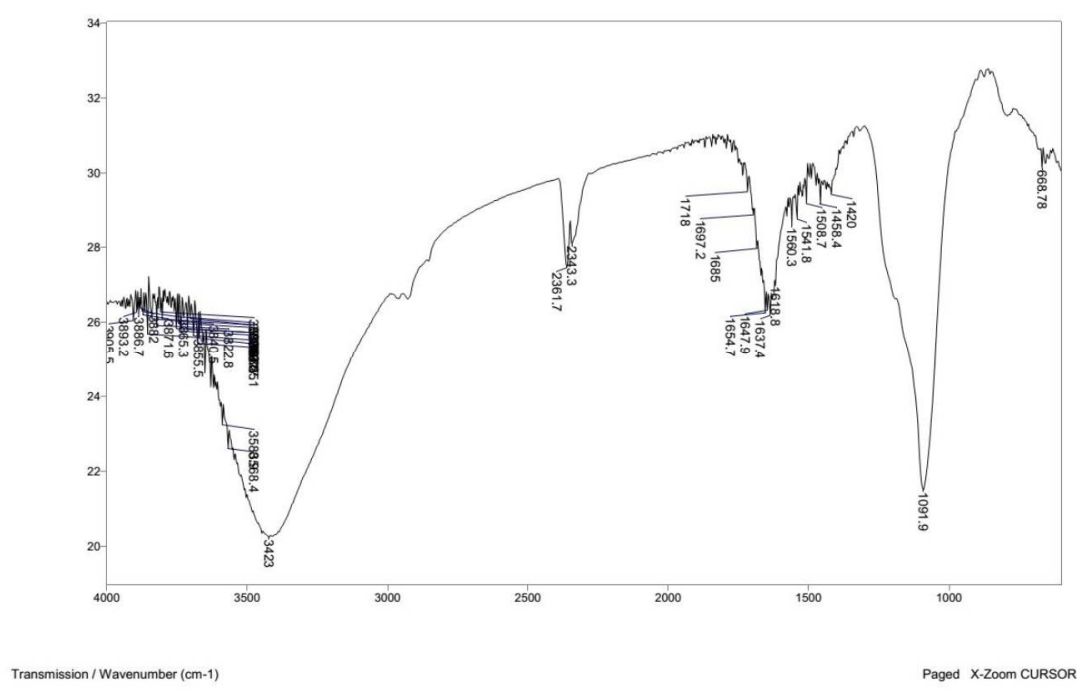

Fig. 2. FTIR spectrum of $S$. costatum.

By GC-MS analysis, the extract of $S$. costatum was found to have a mixture of volatile compounds. A total of 10 peaks were observed with respective retention times in GC-MS chromatogram (Fig. 3). The main chemical-constituent was 16-octadecanoic acid, methyl ester (tR $=10.30 \mathrm{~min})(48.05 \%)$ followed by pentadecanoic acid, 13 methyl, methyl ester $(\mathrm{tR}=9.40 \mathrm{~min})$ 


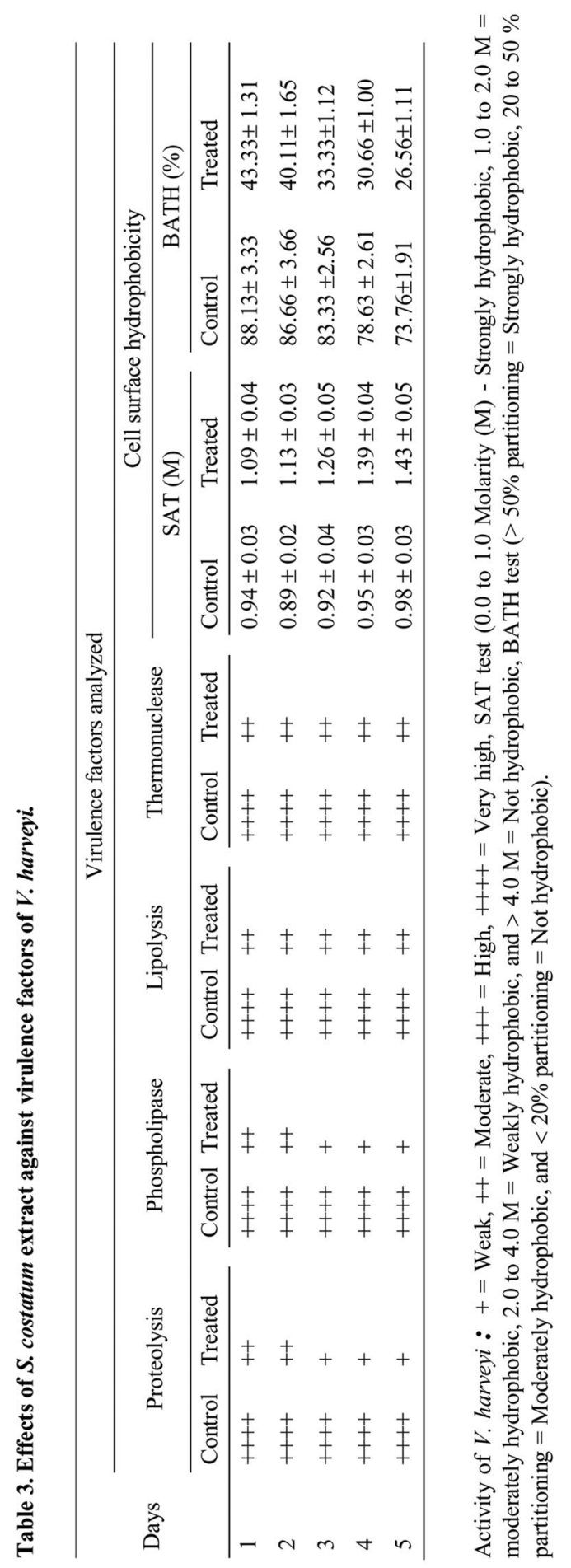




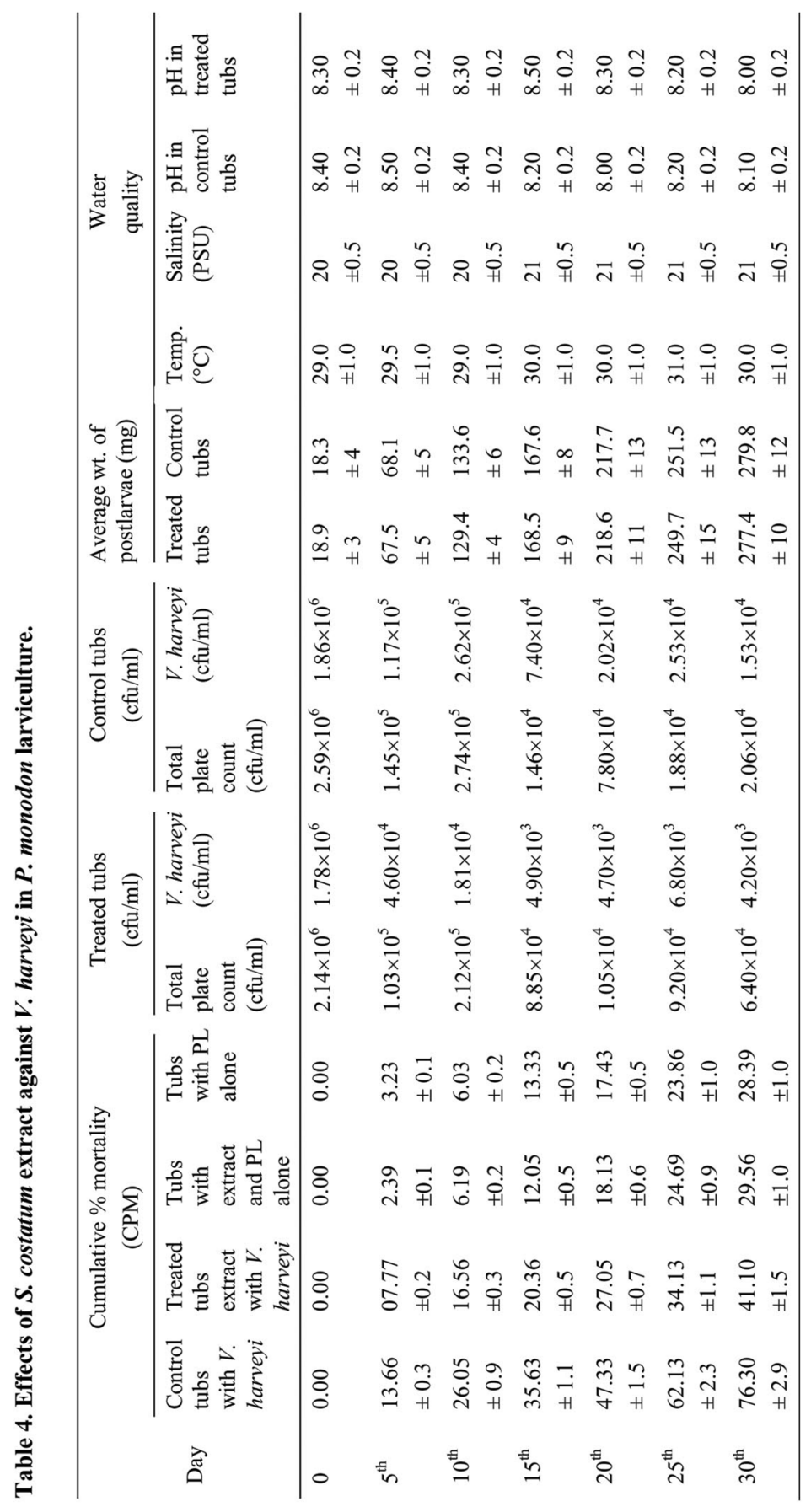


(18.94\%). When S. costatum extract was tested against $V$. harveyi during larviculture, the reduction on the cumulative percentage of mortality (CPM) in P. monodon larvae was $35.20 \pm 0.6$, compared to control $(76.30 \pm 0.8)$. On the 30th day of sampling, the average weights of the PL were $279.8 \pm 0.01 \mathrm{mg}$ and $277.4 \pm 0.02 \mathrm{mg}$ for control and treatment, respectively and were not considerably dissimilar from one another. The maximum decrease of luminous $V$. harveyi counts, observed during 30 days ranged from $4.60 \times 10^{4}$ to $6.80 \times 10^{3} \mathrm{cfu} / \mathrm{ml}$, respectively, compared to control $\left(1.17 \times 10^{5}\right.$ to $\left.1.53 \times 10^{4} \mathrm{cfu} / \mathrm{ml}\right)($ Table 4$)$. Water quality parameters did not change significantly in treatment (Table 4) and control. However, in the treatment, with extract alone, there was the development of a slight greenish colour was noticed as compared to control, possibly due to the crude nature of the extract.

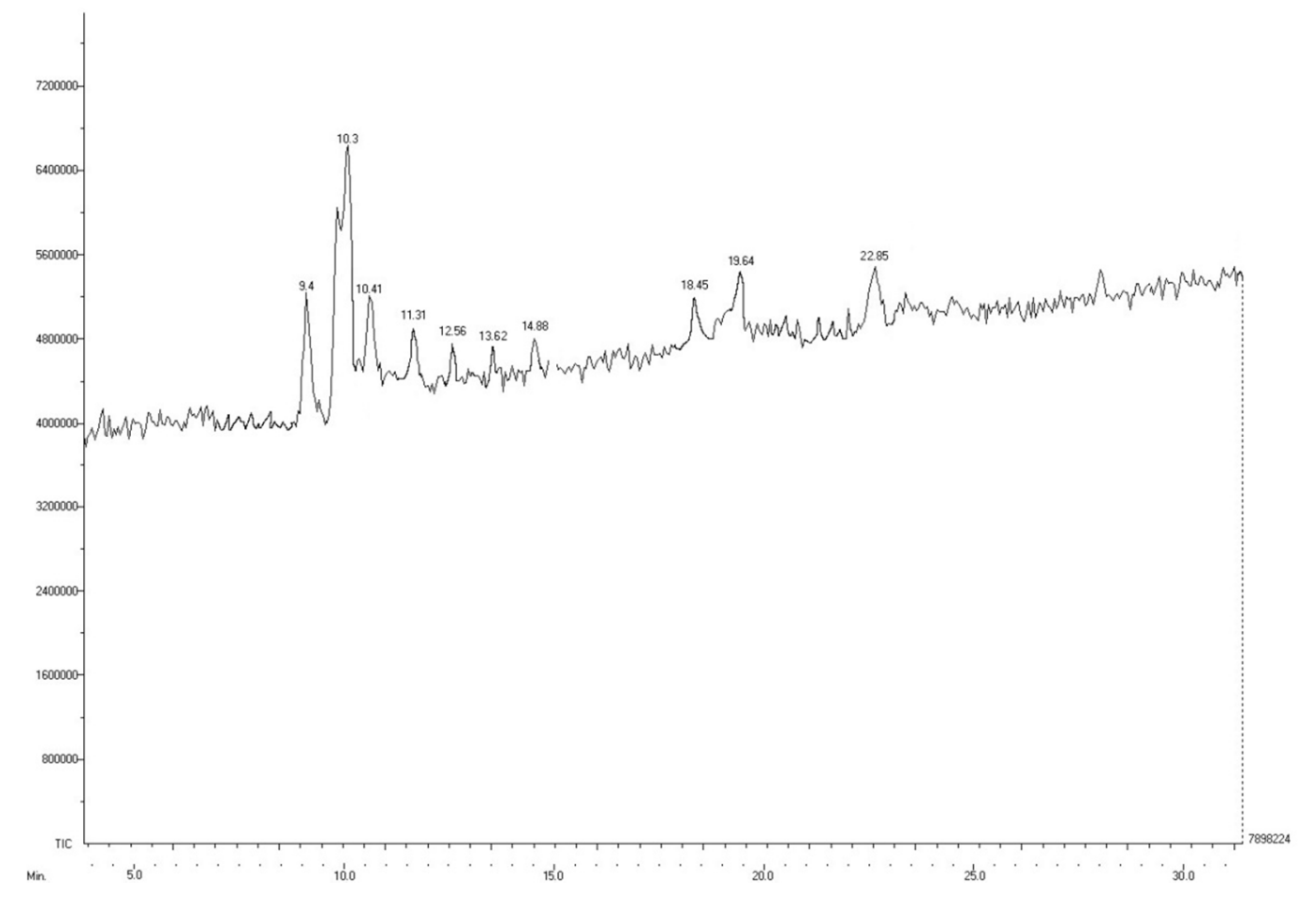

Fig. 3. GC-MS chromatogram of crude ethyl acetate extract of S. costatum.

Unicellular algae such as Chaetoceros, Tetraselmis spp., S. costatum and Isochrysis galbana @ 40,000 to $1,00,000$ cells $/ \mathrm{ml}$ are being used for the developmental stages of penaeid shrimps. Hence, the crude extract of $S$. costatum also has a prospective for use in shrimp larviculture. Fatty acids having a chain length of more than 10 carbon atoms would induce lysis of bacterial protoplasts and may also affect the expression of bacterial virulence factors, which are essential for the establishment of an infection. It is reported that lipids inhibit microbes by disrupting cellular membrane (Bergsson et al. 2011) of bacteria, fungi and yeasts. Organic extract of $S$. costatum exhibited antagonism against $V$. fisheri and V. parahaemolyticus (Naviner et al. 1999)

The outcome of this study specifies that the crude extract of $S$. costatum showed a zone of inhibition on $V$. harveyi @ $300 \mu \mathrm{g}$ and also has decreased its virulence factors. During co-culture, $S$. costatum reduced the growth of $V$. harveyi. When $S$. costatum extract was tested against $V$. harveyi during $P$. monodon larviculture, a reduction on the cumulative percentage of mortality 
(35.20 $\pm 0.6 \%)$ was noticed on P. monodon larvae. It could be inferred that $S$. costatum extract can be used as bio-agent for controlling $V$. harveyi. Application of natural bio-agent like $S$. costatum extract would moderate the undesirable contamination from applying the chemical compounds with reduced cost and eco-friendly nature. However, more studies on docking of algae molecules are necessary before using such extracts as therapeutic agents in shrimp larviculture.

\section{Acknowledgements}

The authors thankfully acknowledge the Department of Biotechnology, Government of India for funding the project (BT/PR/13383/AAQ/03/501/2009) "Development of inhibitors for controlling quorum sensing luminescence disease-causing Vibrio harveyi in shrimp larviculture system".

\section{References}

Austin B and Zhang XH 2006. Vibrio harveyi: A significant pathogen of marine vertebrates and invertebrates. Lett. Appl. Microbiol. 43: 119-124.

Bergsson G, Hilmarsson H and Thormar H 2011. Antibacterial, antiviral and antifungal activities of lipids. In: Lipids and essential oils as antimicrobial agents, H. Thormar (Eds), pp. 47-80. John Wiley and Sons Limited Chichester, United Kingdom.

Chellaram C, Sreenivasan S, Anand TP, Kumaran S, Kesavan D and Priya G 2011. Antagonistic bacteria from live corals, Tuticorin coastal waters, South-eastern India. Pakistan. J. Pharmacological Sci. 24:175-181.

Das BK, Pradhan J, Pattnaik P, Samantaray BR and Samal SK 2005. Production of antibacterials from the freshwater alga Euglena viridis (Ehren). World. J. Microbiol. Biotechnol. 21: 45-50.

Dineshkumar M, Kannappan S and Sivakumar K 2017a. Effect of mangrove plant Sesuvium portulacastrum extract against $V$. harveyi during shrimp larviculture. J. Environ. Biology 38: 48-53.

Dineshkumar R, Kumaravel R and Sampathkumar P 2017b. Cultivation of efficient marine microalgae and their biochemical composition and its antibacterial activity against human pathogens. J. Aquac. Mar. Biol. 5: 00127.

D'Souza L, Devi P, Shridhar DM and Naik CG 2008. Use of Fourier Transform Infrared (FTIR) spectroscopy to study cadmium-induced changes in Padina tetrastromatica (Hauck). Anal. Chem. Insights 3: $135-43$.

Duygu D, Udoh AU, Ozer T, Akbulut A, Erkaya I, Yildiz K and Guler D 2012. Fourier Transform Infrared (FTIR) spectroscopy for identification of Chlorella vulgaris Beijerinck 1890 and Scenedesmuss obliquus (Turpin) Kutzing 1833. Afr. J. Biotechnol. 11: 3817-3824.

Elumalai S and Sakthivel R 2013. GC-MS and FT-IR spectroscopic determination of fatty acid methyl ester of 16 freshwater microalgae, isolated from cement industries of Tamil Nadu, India. J. Algal. Biomass.Utilization. 4: 50-69.

Guillard RRL and Ryther JH 1962. Studies on marine planktonic diatoms I, Cyclotella nana Hustedt and Detonula confervacae (Cleve) Gran. Can. J. Microbiol. 8:229-239.

Maiti B, Malathi S, Rekha K, Karunasagar I and Karunasagar I 2009. Evaluation of RAPD-PCR and protein profile analysis to differentiate Vibrio harveyi strains prevalent along the Southwest coast of India. J. Genetics 88: 273-279.

Kannappan S, Sivakumar K and Sethi S 2018. Protective effect of mangrove (Rhizophora apiculata) leaves extract in shrimp (Penaeus monodon) larvae against bio-luminescent disease-causing Vibrio harveyi bacteria. Spanish J. Agricult. Res. 16(1): e0501.

Musharraf SG, Ahmed MA, Zehra N, Kabir N, Choudhary MI and Rahman AU 2012. Biodiesel production from microalgal isolates of southern Pakistan and quantification of FAMEs by GC-MS/MS analysis. Chemistry. Central. J. 6: 149. 1-10.

Natrah FM, Bossier P, Sorgeloos P,Yusoff FM and Defoirdt T 2014. Significance of microalgal-bacterial interactions for aquaculture. Rev. Aquaculture 6: 48-61. 
Naviner M, Berge JP, Durand P and Le-Bris H 1999. Antibacterial activity of the marine diatom Skeletonema costatum against aquacultural pathogens. Aquaculture. 174: 15-24.

Prartono T, Kawaroe M and Vicky K 2013. Fatty acid composition of three diatom species Skeletonema costatum, Thalassiosira sp. and Chaetoceros gracilis. Int. J. Environ. Bioenergy 6: 28-43.

Raissy M, Momtaz H, Moumeni M, Ansari M and Rahimi E 2011. Molecular detection of Vibrio spp in lobster hemolymph. Afr. J. Microbiol. Res. 5:1697-1700.

Rangaia SG, Lakshmi P and Manjula E 2010. Antimicrobial activity of seaweeds Gracillaria, Padina and Sargassum spp. on clinical and phytopathogens. Int. J. Chem. Analytical Sci. 1: 114-117.

Shanmugapriya R and Ramanathan T 2011. Screening for antimicrobial activity of crude extracts of Skeletonema costatum. J. Appl. Pharmacol. Sci. 1: 154-157.

Soto-Rodriguez SA, Gomez-Gil B, Lozano R, del Rio-Rodriguez R, Dieguez AL and Romalde JL 2012. Virulence of Vibrio harveyi responsible for the "Bright-red" syndrome in the Pacific white shrimp Litopenaeus vannamei. J. Invertebrate Pathol. 109: 307-317.

Taylor RL, Abrahamsson K, Godhe A and Wangberg SA 2009. Seasonal variability in polyunsaturated aldehyde production potential among strains of Skeletonema marinoi. J. Phycology. 45: 46-53.

Tandel GM, John KR, Rosalind George M and Prince Jeyaseelan MJ 2017. Current status of viral diseases in Indian shrimp aquaculture. Acta.Virol. 61: 131-137.

Tendencia EA, Fermin AC, Dela-Pena MR and Choresca Jr CH 2006. Effect of Epinephelus coioides, Chanos chanos and GIFT Tilapia in polyculture with Penaeus monodon on the growth of the luminous bacteria Vibrio harveyi. Aquaculture 253: 48-56.

Traifalgar RF, Serrano AE, Corre V, Kira H, Tung HT, Fady RM, Kader MA, Laining A, Yokoyama S, Ishikawa M and Koshio S 2009. Evaluation of dietary fucoidan supplementation effects on growth performance and Vibriosis resistance of Penaeus monodon postlarvae. Aquaculture Sci. 57: 167-174.

Yamasaki Y, Ohmichi Y, Shikata T, Hirose M, Shimasaki Y, Oshima Y and Honjo T 2011. Species-specific allelopathic effects of the diatom Skeletonema costatum. Thalassas 27: 21-32.

Yin NC, Yaakob Z, Ali E, Min AE and Wa NS 2011. Characterization of various microalgae for biodiesel fuel production. J. Mater. Sci. Engg. A1: 80-86.

(Manuscript received on 29 July, 2019; revised on 4 April, 2020) 